\title{
Molecular handoffs in nitrergic neurotransmission
}

\section{Arun Chaudhury* \\ Department of Surgery, Brigham and Women's Hospital, Harvard Medical School and VA Boston Healthcare System, Boston, MA, USA}

\section{Edited by:}

Yeong Yeh Lee, University of Glasgow, UK

\section{Reviewed by:}

Marcel Jimenez, Universidad Autónoma de Barcelona, Spain

Jacqueline Nelisis Zanoni,

Universidade Estadual de Maringá,

Brazil

\section{${ }^{*}$ Correspondence:}

Arun Chaudhury, Department of Surgery, Brigham and Women's Hospital, VA Medical Center, Research 151, Room 2B126, Building 3, 1400 VFW Parkway, West Roxbury, Boston, MA 02132, USA

e-mail: arun_chaudhury@

hms.harvard.edu;

arunchaudhury.boston@gmail.com
Postsynaptic density (PSD) proteins in excitatory synapses are relatively immobile components, while there is a structured organization of mobile scaffolding proteins lying beneath the PSDs. For example, shank proteins are located further away from the membrane in the cytosolic faces of the PSDs, facing the actin cytoskeleton. The rationale of this organization may be related to important roles of these proteins as "exchange hubs" for the signaling proteins for their migration from the subcortical cytosol to the membrane. Notably, PSD95 have also been demonstrated in prejunctional nerve terminals of nitrergic neuronal varicosities traversing the gastrointestinal smooth muscles. It has been recently reported that motor proteins like myosin Va play important role in transcytosis of nNOS. In this review, the hypothesis is forwarded that nNOS delivered to subcortical cytoskeleton requires interactions with scaffolding proteins prior to docking at the membrane. This may involve significant role of "shank," named for SRC-homology (SH3) and multiple ankyrin repeat domains, in nitric oxide synthesis. Dynein light chain LC8-nNOS from acto-myosin Va is possibly exchanged with shank, which thereafter facilitates transposition of nNOS for binding with palmitoyl-PSD95 at the nerve terminal membrane. Shank knockout mice, which present with features of autism spectrum disorders, may help delineate the role of shank in enteric nitrergic neuromuscular transmission. Deletion of shank3 in humans is a monogenic cause of autism called Phelan-McDermid syndrome. One fourth of these patients present with cyclical vomiting, which may be explained by junctionopathy resulting from shank deficit in enteric nitrergic nerve terminals.

Keywords: nitrergic, neurotransmission, shank, autism, functional bowel disorders, LC8, PSD95, inhibitory neurotransmission

\section{MERE LOCALIZATION OF nNOS IN PREJUNCTIONAL NERVE} TERMINALS IS INADEOUATE FOR NITRIC OXIDE SYNTHESIS Defective neuromuscular transmission is a major pathophysiological basis for gastrointestinal motility disorders (1-3). Large repertoire of these disorders results from defective inhibitory neurotransmission that involves release of nitric oxide from prejunctional nerve terminals of motor neurons that traverse the smooth muscle layers of the gut (4-7). Failure of nitric oxide synthesis, the major inhibitory neurotransmitter, results in a phenotype that involves complete failure of gut smooth muscle relaxation (8). Though human biopsy samples of functional bowel disorders are difficult to obtain for obvious reasons, animal studies have provided ambiguous results regarding concentrations of nNOS in nerve terminals in pathological states $(9,10)$, which phenotypically manifest as either failure of relaxation of intestinal smooth muscles or varying degrees of impairment of gastrointestinal transit $(11,12)$. However, recent studies have provided evidence that mere presence of nitric oxide synthesizing-enzyme neuronal nitric oxide synthase (nNOS) in the nerve terminals may not be adequate for inhibitory nitrergic neuromuscular transmission in the gut $(11,12)$.

Nitric oxide-mediated neurotransmission, the main basis for oro-aboral movement of intestinal luminal contents, may be disrupted due to several factors, including (i) transcriptional blockade of genomic nNOS synthesis $(13,14)$, (ii) deficit in specific splice variants like $\mathrm{nNOS} \alpha$, because these splice variants have the capability to undergo lipidic modification to remain membraneassociated through N-terminal PDZ-interacting domain $(15,16)$, (iii) defect in allosteric proteins and cofactors like tetrahydrobiopterin (BH4) and LC8 (15, 17-20), (iv) defects in dimerization $(16,18,21,22)$, and (v) defective transport of nNOS within the nerve terminals due to cytoskeletal abnormalities, which do not favor enzymatic synthesis of nitric oxide $(11,12,23)$.

Diverse organ systems reveal that nNOS remains membranebound during enzymatic synthesis, suggesting that membrane localization of nNOS may be critical for enzyme action in a physiological context $(5,24-33)$. Evidence has suggested the role of motor proteins like myosin $\mathrm{Va}$ in transposition of $\mathrm{nNOS}$ within the nerve terminals to the membranes to facilitate nitrergic neurotransmission $(11,12)$.

\section{POSSIBLE ROLE OF ACTIN CYTOSKELETAL BARRIER IN} NITRIC OXIDE SYNTHESIS DURING AN ACTION POTENTIAL

A thesis is proposed here, based on rational argument that depletion of the cytoskeletal organizer protein shank3 may result in defective nNOS membrane localization, resulting in defective nitric oxide synthesis. nNOS is a water soluble protein, but a portion of nNOS within nerve terminals remains membrane-bound due to its ability to undergo lipidic interaction with palmitoylPSD95 $(15,34)$. Membrane-bound nNOS may be at an optimal cellular localization for nitric oxide synthesis, possibly due to proximity to calcium ion channels (12). Myosin Va facilitates cytosolic 
transport of nNOS to the subcortical region of the nerve terminal that is rich in actin (12). Actin meshwork has been reported to provide a physical barrier to vesicles involved in neurotransmission (35-44). Specific dynamics regarding correlation of synaptic activity and reorganization of cortical actin has been examined in some neuronal systems $(39,45-48)$, but has not been tested in enteric nerve terminals.

The critical role of filamentous actin in determining the extent of dynamic reorganization in postsynaptic density (PSD) molecular composition is being increasingly recognized (49-52). It is not known whether actin network may provide a barrier to diffusion of non-vesicular neurotransmitter synthesizing enzymes like nNOS, but recent evidence suggests that the cytosolic streaming of water soluble molecules is not a chaotic stochastic event (53), but rather relies on the cytoskeletal machinery like myosin Va and actin for specific domain localization $(11,12,54)$. Recently, the role of rare actin mutations in refractory constipation has also been recognized $(55,56)$.

\section{POSSIBILITY OF "SHANK" PROTEINS AS ORGANIZATIONAL UNIT IN ENTERIC INHIBITORY JUNCTIONS: MOLECULAR EXCHANGES DURING NITRERGIC SYNTHESIS}

In excitatory synapses, the PDZ-domain-containing scaffold proteins PSD95, along with the shank family form a bilayer protein network below the postsynaptic membrane, which is bridged by guanylate kinase-associated protein (GKAP) (57). Shank protein has three different isoforms: shanks1, 2, and $3(58,59)$. Shank-family scaffolds are further linked to actin filaments via cortical-actin-binding protein (cortactin) (60). Thus, these shank proteins form sheets that make a synaptic platform $(61,62)$. Depletion and redistribution have been shown for ProSAP2/shank3 in PSDs of cultured neurons, an observation which was independent from protein synthesis or degradation and could be enhanced by electrophysiological stimulation (63). Whether such laminar organization occurs in enteric nitrergic nerve terminals is not known. Importantly, scaffolding proteins like PSD95, which are normal constituents of postsynaptic compartments, may also be present in presynaptic region, including enteric nerve terminals $(15,64)$.

Myosin Va has been shown to interact with nNOS via DLC8 (dynein light chain, $8 \mathrm{kDa}$ MW) $(12,20,65)$. LC8 acts as multiple cargo adapters and provides a hub for protein homo- and heterodimerization $(66,67)$. LC8, also called DLC8, has been reported to bind to presynaptic components like bassoon, which form cytomatrix of the active zone (66). LC8 has also been reported to associate and form macromolecular complex with shank (68).

Initial evidence has suggested the plausible existence of an "active zone" for nNOS in the membrane of these nerve terminals (15). nNOS is tethered to the nerve terminal membrane via the PDZ-rich protein PSD95 (15). PSD95, apart from its PDZ domains, also have other protein domains like $\mathrm{SH} 3$ and guanylate kinase $(69,70)$. nNOS may undergo molecular exchange in the region of the cortical cytoskeleton in which acto-myosin Va-bound nNOS initiates association with shank, a cortical actin-bound scaffolding protein.

Shank protein has different modular domains like multiple ankyrin repeats, $\mathrm{SH} 3, \mathrm{PDZ}$, and sterile alpha motif, which all can function as protein interaction units. These aspects have been reviewed in details elsewhere (57). Figure $\mathbf{1}$ is a STRING analyses that shows shank proteins are widely distributed in nature in both the plant and animal kingdom. Furthermore, curated analyses show that shank 3 and shank2 interact with multiple proteins that are known to be present and functional in both postsynaptic and presynaptic compartments. In the nitrergic nerve terminals, nNOS may bind to PSD95 in the membrane from shank via transposition through GKAP. PDZ-domain-mediated transfer of these proteins or molecular exchange via LC8 may occur at the cortical cytoskeleton of the enteric nerve terminal periphery. The logistics of this hypothesis is represented in a cartoon (Figure 2). These molecular exchanges may be viewed by time-lapse NMR experiments or by live imaging of enteric varicosities with evanescent microscopy or fluorescence correlation spectroscopy.

Predictive in silico analyses shows that shank3 has the potential to interact with both nNOS (Figure 3) and LC8 (Figure 4). This makes it likely that LC8 acts as an exchange factor that helps transcend sub-terminally located nNOS through the actin meshwork to membrane-bound PSD95. Dialyzates of membrane and cytosol have shown that membrane fractions of enteric nerve terminals lack LC8 (20). Proteomic analyses have shown that LC8 can bind to actin (73). It is thus likely that LC8, shank, and GKAP mediates transfer of nNOS in the subcortical zone of the nerve terminal, and that the subcortical zone of the nerve terminal is a critical zone for nitrergic neurotransmission. PSD95-nNOS complex may be formed in the cytosol but it is probably not feasible for this macromolecular complex to be transported to the membrane. Rigidly bound nNOS to PSD95 will not favor efficient neurotransmission. This mainly results from the state of the membrane potential in the region of the nerve terminal, which imperatively has to be closely correlated with the activity state of the nNOS enzyme. The loose associations between nNOS and LC8, myosin Va, PSD95, and possibly shank and GKAP add to the complexity of regulation of how nNOS is transported within the terminal but probably favor a state of switching between active and inactive enzyme function. This toggle nature is important for start and stop of nitrergic neurotransmission with classical Sherringtonian concepts.

Both shank3 and shank2 has been reported to be present in nNOS-positive myenteric neuronal cell body (79) (Figure 5). Shank protein presence has been described in the gut $(80,81)$, though it has not been examined specifically in the nitrergic nerve terminal. Messages for shank-interacting proteins like SHARPIN have been described from entire gut muscle extracts of wild-type mice (82). Testing important components of the role of shank in nitrergic neurotransmission are current goals of the laboratory.

\section{SHANK PROTEINS MAY PLAY SIGNIFICANT FUNCTION IN ENTERIC NITRERGIC NEURO-SMOOTH MUSCLE NEUROTRANSMISSION BY FACILITATING TRANSFER OF CYTOSOLIC nNOS TO MEMBRANE THROUGH THE CORTICAL CYTOSKELETON}

Intriguingly, myosin Va-associated scaffolding proteins like "shank" have been reported to be depleted in monogenic conditions that result in manifestation as pervasive neurodevelopmental disorder (PND) (83). For example, 25\% of patients with the rare condition Phelan-McDermid syndrome report refractory and 


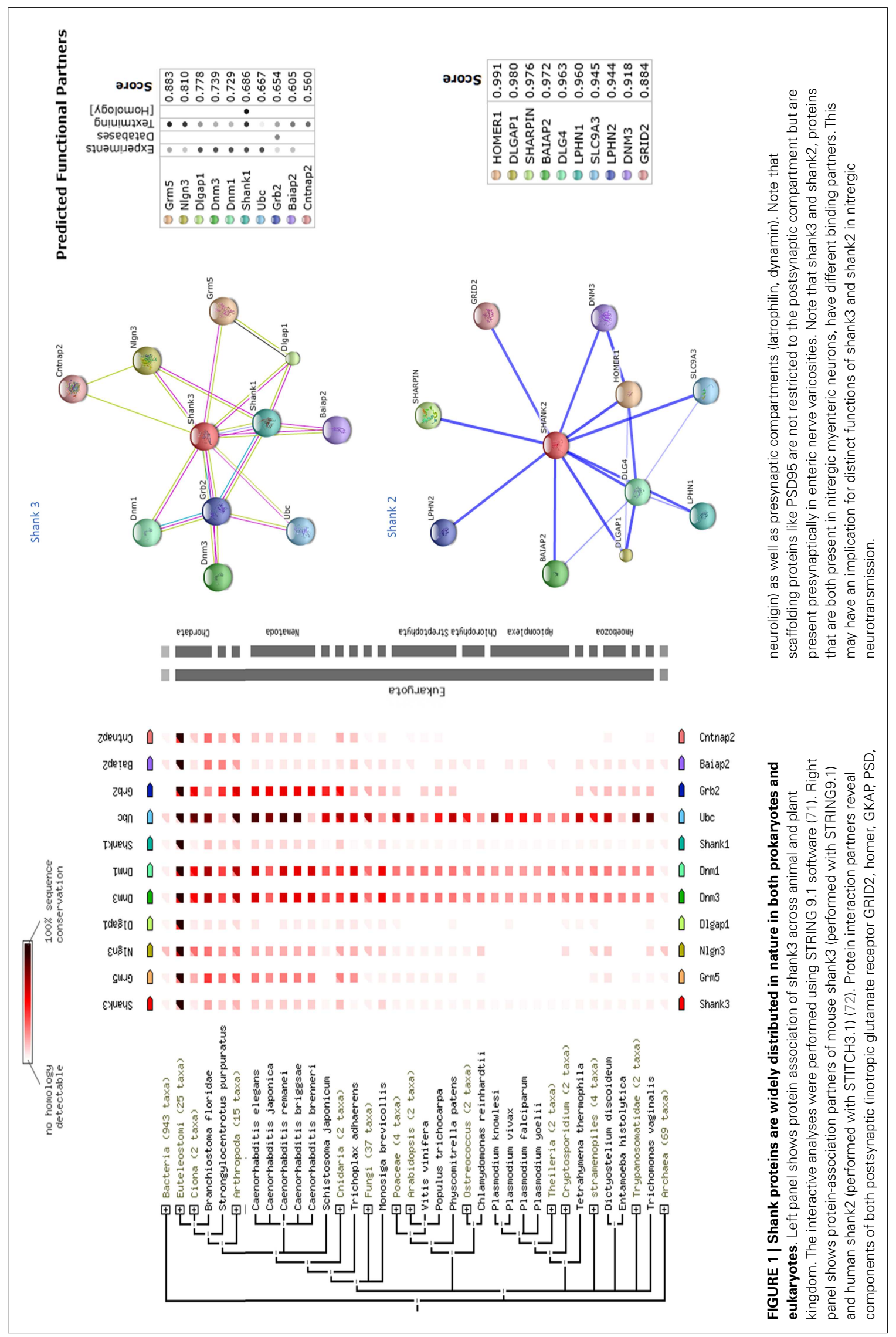



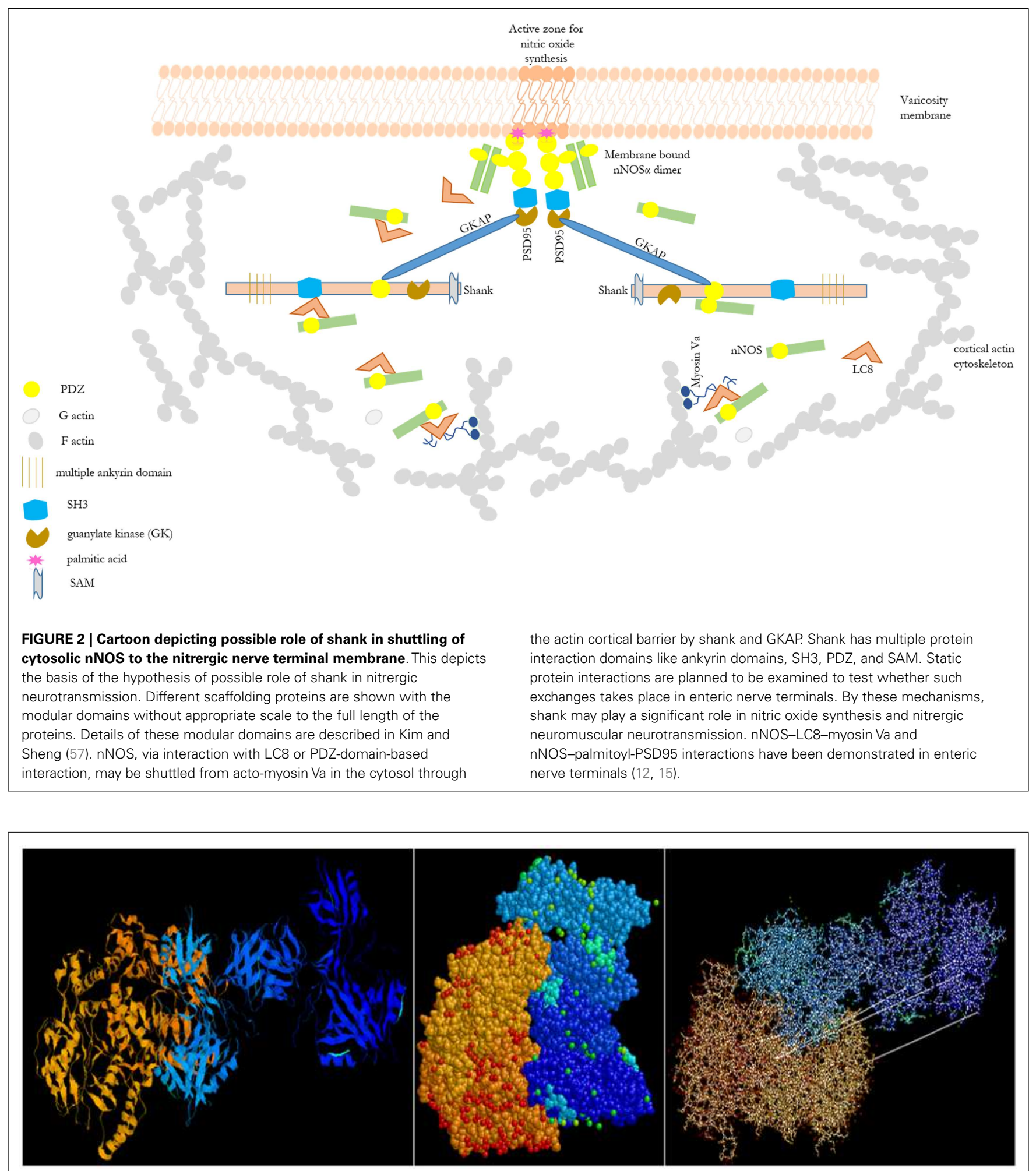

FIGURE 3 | Predictive bioinformatic analyses shows potential interaction between shank3 and nNOS. Rat proteins (PDB: 30JN, shank3; 10M4, nNOS) were queried for interaction using Patchdock. Refinement of solutions was performed using Firedock. Protein interaction predictions were performed based on van der Waals and electrostatic interactions between the
3D structures. Prediction of structural alignment based on lowest energy levels were visualized for ribbons and ball and stick structures using RASMOL and depicted here from different angles. Patchdock software uses surface configurations of folded proteins to predict interactions using computer vision technology (74-76) and is currently being used in neuroinformatics (77). 

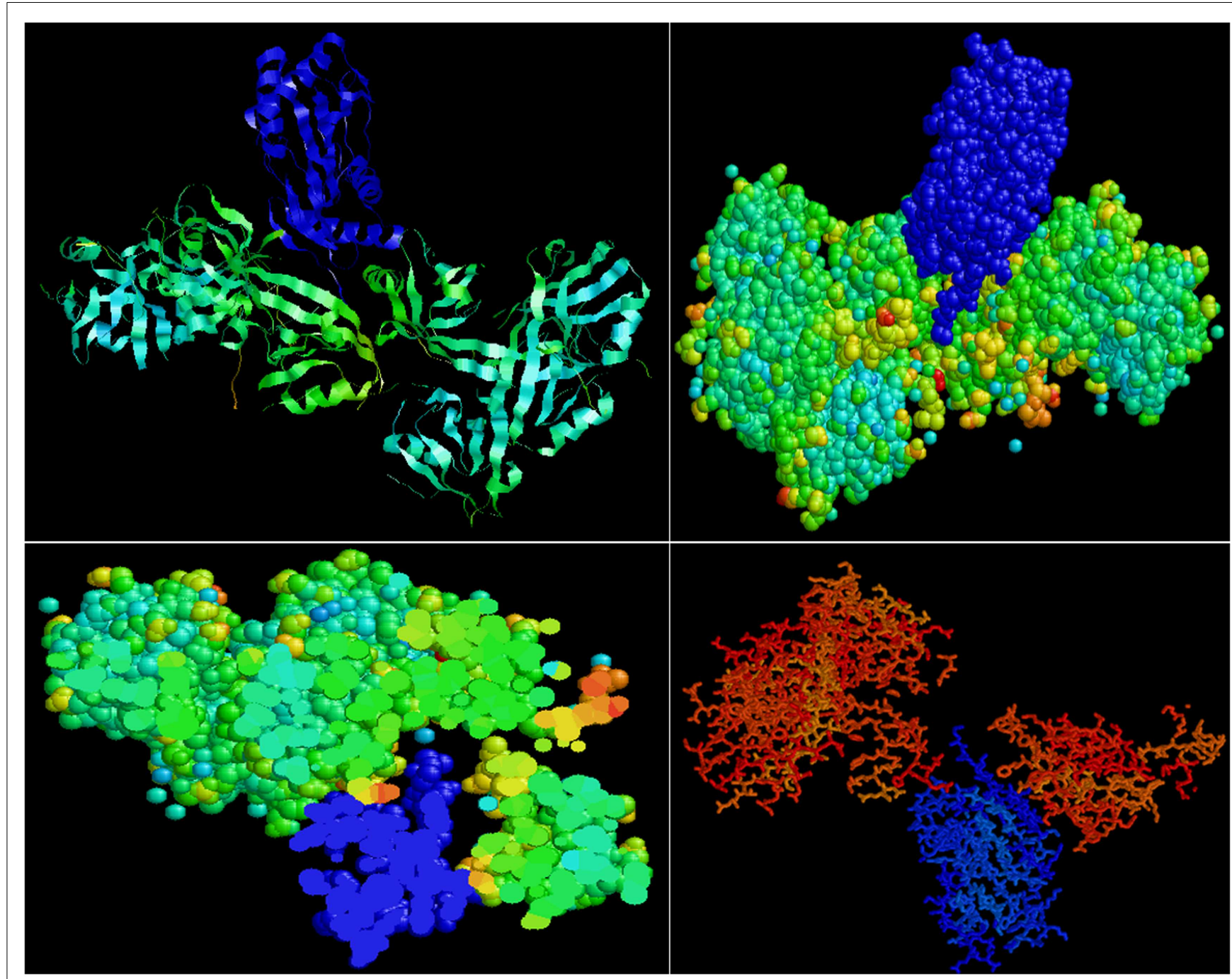

FIGURE 4 | Predictive bioinformatic analyses shows potential interaction between shank3 and LC8. Rat proteins (PDB: 3QJN, shank3; 1F96, nNOS-bound LC8) were queried for interaction using Patchdock. Refinement of solutions was performed using Firedock. Protein interaction predictions were performed based on van der Waals and electrostatic interactions between the 3D structures. Prediction of structural alignment based on lowest energy levels was visualized for ribbon and ball and stick structures using RASMOL (78) and shown in upper panels. In the lower panels, note the groove in the shank in which the LC8 (blue) fits. Such conformation may offer dynamic stability to shank-LC8-nNOS complex during transport at the periphery of nerve terminals. cyclical vomiting (84-87). Chromosome mutations like deletions are seen in chromosome 22 in this syndrome (del22q13.3) (88, 89). This results in inhibition of synthesis of the protein shank3 (90). Shank proteins [Src-homology domain 3 (SH3) and multiple ankyrin repeat domains], including shank3, are known protein interaction partners of myosin Va (68, 91-94).

Gastrointestinal motility disorders affecting both the proximal and distal portions of the gut affect quality of daily life in both children and adult subjects with autism spectrum disorders (ASD) (95-97). These gastrointestinal motility problems manifest as dysphagia, achalasia, refractory or cyclical vomiting, acid reflux, gastroparesis and defect in gastric emptying, intestinal stasis and pseudo-obstruction, and chronic constipation (86, 98106). Dysphagia in these patients, gastroesophageal reflux, chronic vomiting, or encopresis and chronic constipation are often misconstrued in the clinical setting as behavioral issues, rather than an organic problem (107-109).

In diverse systems, myosin Va-LC8-nNOS have been shown to form complexes with shank-GKAP-PSD95 $(68,73,110)$. This important issue merits examination in enteric motor terminals. Shank has also been reported to associate with cell adhesion molecules like neuroligins in the postsynaptic compartment. Changes through neuroligin-neurexin signaling have been proposed in the presynaptic compartment during neuronal activity $(111,112)$. Additionally, neuroligin defects have been suggested as a pathophysiological basis for defective gastrointestinal neurotransmission in autism (113). Though NO signaling may not be spatially localized because of the very high diffusion coefficient 


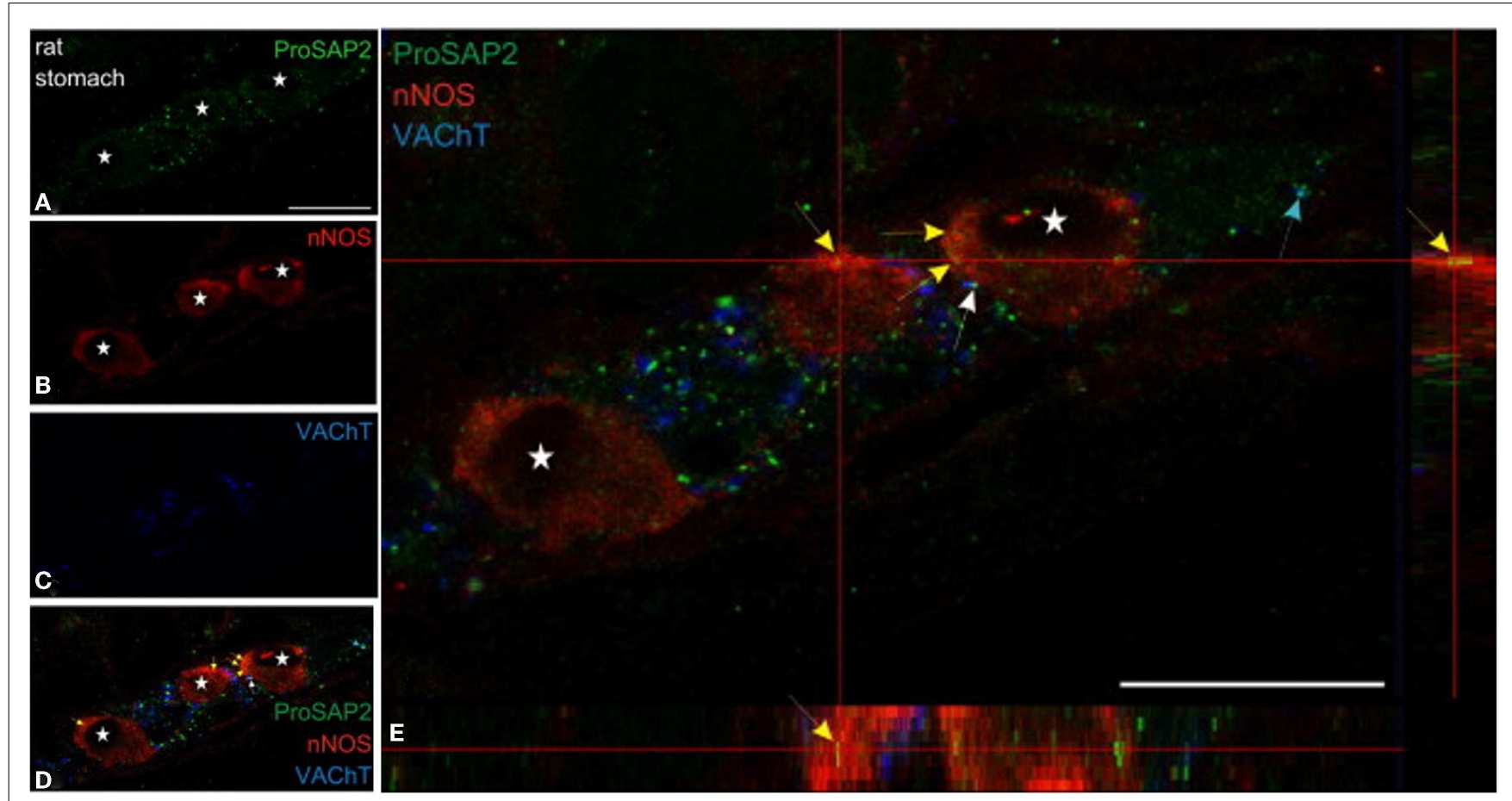

FIGURE 5 | Shank3 is present in soma of myenteric nitrergic neuron Note that shank3 has speckled appearance in cell periphery (A). (B-D) shows staining for nNOS, vAChT and colocalization of the three proteins. In (E), higher magnification view shows the speckled appearance of shank, which is still seen as diffuse distribution across the cell body, but it is not clear whether the distribution is only restricted to the surface. The higher power image shows diffuse distribution of nNOS in the both the cell cytosol and membranous region, colocalized with the submembranous location of shank3. Note that shank3 localization in nitrergic nerve terminals has not been examined. Modified with permission from Raab et al. (79).
$(114,115)$, specific role of cell adhesion molecules in nitrergic neurotransmission has not been examined in details.

Shank2 may also play a role in nitrergic neurotransmission in enteric neuro-smooth muscle junctions. Shank2-guanine nucleotide exchange factor ArhGEF interactions has been reported (116). Deletion of ArhGEF in mice has been shown to develop esophageal achalasia $(117,118)$. Both shank2 and shank1 mutations have also been reported recently to present with autism features $(88,119-121)$. The role of shank2/shank 1 in enteric nitrergic neurotransmission may also be significant, though the presence of shank1 in nitrergic myenteric neurons was not reported in the study by Raab et al. (79).

\section{SHANK KNOCKOUT MICE MAY PROVIDE INSIGHTS INTO MECHANISTIC BASIS OF CYCLICAL VOMITING}

Though the experiments of dynamically examining molecular exchanges by real-time live imaging may not be easily accomplished without access to high resolution microscopy, protein association studies by imaging proximity ligation assay (PLA) (12, 122) may be utilized to obtain a snapshot of static interactions in the cell periphery. Nitric oxide production assays by $\mathrm{KCl}$ stimulation of diaminofluorescein (DAF)-loaded enteric varicosities may be used to examine deficiency of nitric oxide production in shank3 knockout mice. Shank $3^{\text {exon4-9 }}$ homozygotes result in nearly complete loss of shank3a and b isoforms (123). It has been reported that these shank3 knockout mice manifest behavioral patterns of autism (123-126). Defective nitrergic neurotransmission due to shank deficiency may impair gastric emptying. These studies shall provide critical insights into the molecular pathology of refractory gastrointestinal motility disorders like cyclical vomiting in patients with ASD.

Insights into molecular pathogenesis shall set the stage for long-term investigations into designing rational pharmacological targets for addressing these conditions. The gastrointestinal symptoms may severely affect nutrition in ASD patients with already compromised social communication skills, so state-of-theart management for gastrointestinal problems is much needed. Gastrointestinal motility problems in these patients are a cause of suffering for the patients, as well as challenging issues for their caregivers including parents. Virtually nothing is known about the mechanisms underlying these disorders. This review argues based on incipient evidence from CNS neuropathology that because synaptopathy is a major underlying pathophysiology of ASD (112, 127-129), the motility problems of slowed gastrointestinal transit possibly result from defective junctional neuromuscular transmission, for example, through defects in nitric oxide-mediated neuro-smooth muscle transmission.

If defects in shank proteins are detected as a cause for impairment of nitrergic neurotransmission, then methods for pharmacological management for treating these disorders, such as replacement of shank proteins that are being reported for management of autism (130-132), may provide benefits for gastrointestinal 
symptoms as well. Shank proteins are known to respond to the enteric-specific neurotrophic factor GDNF via Ret tyrosine kinase signaling (133). These neurotrophic factors may also impact on management of gastrointestinal motility problems that may result from defective shank signaling. This review also supports the rationale of examining shank proteins in impairment of nitrergic neurotransmission in other functional bowel disorders like irritable bowel syndrome and idiopathic gastroparesis.

\section{ACKNOWLEDGMENTS}

The author thanks Dr. Hemant Thatte for encouragement and support through an unrestricted grant from Boston VA Research Institute (BVARI). The author acknowledges pending support from NIH/NINDS (HD082747).

\section{REFERENCES}

1. Gallego D, Malagelada C, Accarino A, De Giorgio R, Malagelada JR, Azpiroz F, et al. Nitrergic and purinergic mechanisms evoke inhibitory neuromuscular transmission in the human small intestine. Neurogastroenterol Motil (2014) 26:419-29. doi:10.1111/nmo.12293

2. Burnstock G. Purinergic signalling in the gastrointestinal tract and related organs in health and disease. Purinergic Signal (2014) 10:3-50. doi:10.1007/ s11302-013-9397-9

3. Thatte HS, He XD, Goyal RK. Imaging of nitric oxide in nitrergic neuromuscular neurotransmission in the gut. PLoS One (2009) 4:e4990. doi:10.1371/ journal.pone. 0004990

4. Boeckxstaens GE, De Man JG, De Winter BY, Herman AG, Pelckmans PA. Pharmacological similarity between nitric oxide and the nitrergic neurotransmitter in the canine ileocolonic junction. Eur J Pharmacol (1994) 264:85-9. doi:10.1016/0014-2999(94)90640-8

5. Van Geldre LA, Fraeyman NH, Peeters TL, Timmermans JP, Lefebvre RA. Further characterisation of particulate neuronal nitric oxide synthase in rat small intestine. Auton Neurosci (2004) 110:8-18. doi:10.1016/j.autneu.2003. 05.001

6. Smits GJ, Lefebvre RA. ATP and nitric oxide: inhibitory NANC neurotransmitters in the longitudinal muscle-myenteric plexus preparation of the rat ileum. Br J Pharmacol (1996) 118:695-703. doi:10.1111/j.1476-5381.1996.tb15456.x

7. Mashimo H, He XD, Huang PL, Fishman MC, Goyal RK. Neuronal constitutive nitric oxide synthase is involved in murine enteric inhibitory neurotransmission. J Clin Invest (1996) 98:8-13. doi:10.1172/JCI118781

8. Adeghate E, al-Ramadi B, Saleh AM, Vijayarasathy C, Ponery AS, Arafat K, et al. Increase in neuronal nitric oxide synthase content of the gastroduodenal tract of diabetic rats. Cell Mol Life Sci (2003) 60:1172-9. doi:10.1007/s00018-0032298-2

9. Pereira RV, de Miranda-Neto MH, da Silva Souza ID, Zanoni JN. Vitamin E supplementation in rats with experimental diabetes mellitus: analysis of myosin- $\mathrm{V}$ and nNOS immunoreactive myenteric neurons from terminal ileum. $J \mathrm{Mol}$ Histol (2008) 39:595-603. doi:10.1007/s10735-008-9200-3

10. Mashimo H, Kjellin A, Goyal RK. Gastric stasis in neuronal nitric oxide synthase-deficient knockout mice. Gastroenterology (2000) 119:766-73. doi: 10.1053/gast.2000.16509

11. Chaudhury A, Cristofaro V, Carew J, Goyal RK, Sullivan MP. Myosin Va plays a role in nitrergic smooth muscle relaxation in gastric fundus and corpora cavernosa of penis. PLoS One (2014) 9:e86778. doi:10.1371/journal.pone. 0086778

12. Chaudhury A, He XD, Goyal RK. Myosin Va plays a key role in nitrergic neurotransmission by transporting nNOS $\alpha$ to enteric varicosity membrane. Am J Physiol Gastrointest Liver Physiol (2011) 301:G498-507. doi:10.1152/ajpgi. 00164.2011

13. Li Y, Li C, Sun L, Chu G, Li J, Chen F, et al. Role of p300 in regulating neuronal nitric oxide synthase gene expression through nuclear factor- $\kappa \mathrm{B}$-mediated way in neuronal cells. Neuroscience (2013) 248:681-9. doi:10.1016/j.neuroscience. 2013.06.030

14. Saur D, Neuhuber WL, Gengenbach B, Huber A, Schusdziarra V, Allescher HD. Site-specific gene expression of nNOS variants in distinct functional regions of rat gastrointestinal tract. Am J Physiol Gastrointest Liver Physiol (2002) 282:G349-58. doi:10.1152/ajpgi.00226.2001

15. Chaudhury A, He XD, Goyal RK. Role of PSD95 in membrane association and catalytic activity of nNOSalpha in nitrergic varicosities in mice gut. Am J Physiol Gastrointest Liver Physiol (2009) 297:G806-13. doi:10.1152/ajpgi. 00279.2009

16. Alderton WK, Cooper CE, Knowles RG. Nitric oxide synthases: structure, function and inhibition. Biochem J (2001) 357:593-615. doi:10.1042/0264-6021: 3570593

17. Gangula PR, Mukhopadhyay S, Ravella K, Cai S, Channon KM, Garfield RE, et al. Tetrahydrobiopterin (BH4), a cofactor for nNOS, restores gastric emptying and nNOS expression in female diabetic rats. Am J Physiol Gastrointest Liver Physiol (2010) 298:G692-9. doi:10.1152/ajpgi.00450.2009

18. Welsh C, Enomoto M, Pan J, Shifrin Y, Belik J. Tetrahydrobiopterin deficiency induces gastroparesis in newborn mice. Am J Physiol Gastrointest Liver Physiol (2013) 305:G47-57. doi:10.1152/ajpgi.00424.2012

19. Gorren AC, Mayer B. Nitric-oxide synthase: a cytochrome P450 family foster child. Biochim Biophys Acta (2007) 1770:432-45. doi:10.1016/j.bbagen.2006. 08.019

20. Chaudhury A, Rao YM, Goyal RK. PIN/LC8 is associated with cytosolic but not membrane-bound nNOS in the nitrergic varicosities of mice gut: implications for nitrergic neurotransmission. Am J Physiol Gastrointest Liver Physiol (2008) 295:G442-51. doi:10.1152/ajpgi.90280.2008

21. Rao YM, Chaudhury A, Goyal RK. Active and inactive pools of nNOS in the nerve terminals in mouse gut: implications for nitrergic neurotransmission. Am J Physiol Gastrointest Liver Physiol (2008) 294:G627-34. doi:10.1152/ajpgi. 00519.2007

22. Gangula PR, Maner WL, Micci MA, Garfield RE, Pasricha PJ. Diabetes induces sex-dependent changes in neuronal nitric oxide synthase dimerization and function in the rat gastric antrum. Am J Physiol Gastrointest Liver Physiol (2007) 292:G725-33. doi:10.1152/ajpgi.00406.2006

23. Su Y, Kondrikov D, Block ER. Cytoskeletal regulation of nitric oxide synthase. Cell Biochem Biophys (2005) 43:439-49. doi:10.1385/CBB:43:3:439

24. Meinen S, Lin S, Rüegg MA, Punga AR. Fatigue and muscle atrophy in a mouse model of myasthenia gravis is paralleled by loss of sarcolemmal nNOS. PLoS One (2012) 7:e44148. doi:10.1371/journal.pone.0044148

25. Mohamed TM, Oceandy D, Zi M, Prehar S, Alatwi N, Wang Y, et al. Plasma membrane calcium pump (PMCA4)-neuronal nitric-oxide synthase complex regulates cardiac contractility through modulation of a compartmentalized cyclic nucleotide microdomain. J Biol Chem (2011) 286:41520-9. doi:10.1074/jbc.M111.290411

26. Finanger Hedderick EL, Simmers JL, Soleimani A, Andres-Mateos E, Marx R, Files DC, et al. Loss of sarcolemmal nNOS is common in acquired and inherited neuromuscular disorders. Neurology (2011) 76:960-7. doi:10.1212/WNL. 0b013e31821043c8

27. Cartwright EJ, Oceandy D, Neyses L. Physiological implications of the interaction between the plasma membrane calcium pump and nNOS. Pflugers Arch (2009) 457:665-71. doi:10.1007/s00424-008-0455-z

28. ElMlili N, Boix J, Ahabrach H, Rodrigo R, Errami M, Felipo V. Chronic hyperammonemia induces tonic activation of NMDA receptors in cerebellum. $J$ Neurochem (2010) 112:1005-14. doi:10.1111/j.1471-4159.2009.06520.x

29. Bredt DS. Targeting nitric oxide to its targets. Proc Soc Exp Biol Med (1996) 211:41-8. doi:10.3181/00379727-211-43950F

30. Oess S, Icking A, Fulton D, Govers R, Müller-Esterl W. Subcellular targeting and trafficking of nitric oxide synthases. Biochem J (2006) 396:401-9. doi:10.1042/BJ20060321

31. Villanueva C, Giulivi C. Subcellular and cellular locations of nitric oxide synthase isoforms as determinants of health and disease. Free Radic Biol Med (2010) 49:307-16. doi:10.1016/j.freeradbiomed.2010.04.004

32. Van Geldre LA, Fraeyman NH, Lefebvre RA. Subcellular localization of neuronal nitric oxide synthase in rat small intestine. Biochem Pharmacol (2000) 60:145-53. doi:10.1016/S0006-2952(00)00289-6

33. Kone BC, Kuncewicz T, Zhang W, Yu ZY. Protein interactions with nitric oxide synthases: controlling the right time, the right place, and the right amount of nitric oxide. Am J Physiol Renal Physiol (2003) 285:F178-90. doi:10.1152/ajprenal.00048.2003

34. Tochio H, Mok YK, Zhang Q, Kan HM, Bredt DS, Zhang M. Formation of nNOS/PSD-95 PDZ dimer requires a preformed beta-finger structure from 
the nNOS PDZ domain. J Mol Biol (2000) 303:359-70. doi:10.1006/jmbi.2000. 4148

35. Lemieux MG, Janzen D, Hwang R, Roldan J, Jarchum I, Knecht DA. Visualization of the actin cytoskeleton: different F-actin-binding probes tell different stories. Cytoskeleton (Hoboken) (2014) 71:157-69. doi:10.1002/cm.21160

36. Trifaró JM, Rodríguez del Castillo A, Vitale ML. Dynamic changes in chromaffin cell cytoskeleton as prelude to exocytosis. Mol Neurobiol (1992) 6:339-58. doi:10.1007/BF02757940

37. Duffney LJ, Wei J, Cheng J, Liu W, Smith KR, Kittler JT, et al. Shank3 deficiency induces NMDA receptor hypofunction via an actin-dependent mechanism. J Neurosci (2013) 33:15767-78. doi:10.1523/JNEUROSCI.1175-13.2013

38. Bleckert A, Photowala H, Alford S. Dual pools of actin at presynaptic terminals. J Neurophysiol (2012) 107:3479-92. doi:10.1152/jn.00789.2011

39. Fonseca R. Activity-dependent actin dynamics are required for the maintenance of long-term plasticity and for synaptic capture. Eur J Neurosci (2012) 35:195-206. doi:10.1111/j.1460-9568.2011.07955.x

40. Sankaranarayanan S, Atluri PP, Ryan TA. Actin has a molecular scaffolding, not propulsive, role in presynaptic function. Nat Neurosci (2003) 6:127-35. doi:10.1038/nn1002

41. Morales M, Colicos MA, Goda Y. Actin-dependent regulation of neurotransmitter release at central synapses. Neuron (2000) 27:539-50. doi:10.1016/ S0896-6273(00)00064-7

42. Goyal RK, Chaudhury A. Structure activity relationship of synaptic and junctional neurotransmission. Auton Neurosci (2013) 176:11-31. doi:10.1016/j. autneu.2013.02.012

43. Siksou L, Rostaing P, Lechaire JP, Boudier T, Ohtsuka T, Fejtova A, et al. Threedimensional architecture of presynaptic terminal cytomatrix. J Neurosci (2007) 27:6868-77. doi:10.1523/JNEUROSCI.1773-07.2007

44. Phillips GR, Huang JK, Wang Y, Tanaka H, Shapiro L, Zhang W, et al. The presynaptic particle web: ultrastructure, composition, dissolution, and reconstitution. Neuron (2001) 32:63-77. doi:10.1016/S0896-6273(01)00450-0

45. Dillon C, Goda Y. The actin cytoskeleton: integrating form and function at the synapse. Annu Rev Neurosci (2005) 28:25-55. doi:10.1146/annurev.neuro.28. 061604.135757

46. Duman JG, Tzeng CP, Tu YK, Munjal T, Schwechter B, Ho TS, et al. The adhesion-GPCR BAIl regulates synaptogenesis by controlling the recruitment of the Par3/Tiam1 polarity complex to synaptic sites. J Neurosci (2013) 33:6964-78. doi:10.1523/JNEUROSCI.3978-12.2013

47. Saneyoshi T, Hayashi Y. The Ca2+ and Rho GTPase signaling pathways underlying activity-dependent actin remodeling at dendritic spines. Cytoskeleton (Hoboken) (2012) 69:545-54. doi:10.1002/cm.21037

48. Rubio MD, Johnson R, Miller CA, Huganir RL, Rumbaugh G. Regulation of synapse structure and function by distinct myosin II motors. J Neurosci (2011) 31:1448-60. doi:10.1523/JNEUROSCI.3294-10.2011

49. Kuriu T, Inoue A, Bito H, Sobue K, Okabe S. Differential control of postsynaptic density scaffolds via actin-dependent and -independent mechanisms. Neuroscience (2006) 26:7693-706. doi:10.1523/JNEUROSCI.0522-06.2006

50. Okabe S. Molecular anatomy of the postsynaptic density. Mol Cell Neurosci (2007) 34:503-18. doi:10.1016/j.mcn.2007.01.006

51. Okabe S. Fluorescence imaging of synapse formation and remodeling. Microscopy (Oxf) (2013) 62:51-62. doi:10.1093/jmicro/dfs083

52. Okabe S. Molecular dynamics of the excitatory synapse. Adv Exp Med Biol (2012) 970:131-52. doi:10.1007/978-3-7091-0932-8_6

53. Shimmen T, Yokota E. Physiological and biochemical aspects of cytoplasmic streaming. Int Rev Cytol (1994) 155:97-139. doi:10.1016/S0074-7696(08) 62097-5

54. Yu JH, Crevanna AH, Bettenbuhl M, Freisinger T, Wedlich-Soldner R. Cortical actin dynamics driven by formins and myosin V. J Cell Sci (2010) 124:1533-41. doi:10.1242/jcs.079038

55. Rubenstein PA, Mayer EA. Familial visceral myopathies: from symptombased syndromes to actin-related diseases. Gastroenterology (2012) 143:1420-3. doi:10.1053/j.gastro.2012.10.031

56. Lehtonen HJ, Sipponen T, Tojkander S, Karikoski R, Järvinen H, Laing NG, et al. Segregation of a missense variant in enteric smooth muscle actin $\gamma$-2 with autosomal dominant familial visceral myopathy. Gastroenterology (2012) 143:1482-91. doi:10.1053/j.gastro.2012.08.045

57. Kim E, Sheng M. PDZ domain proteins of synapses. Nat Rev Neurosci (2004) 5:771-81. doi:10.1038/nrn1517
58. Jiang YH, Ehlers MD. Modeling autism by SHANK gene mutations in mice. Neuron (2013) 78:8-27. doi:10.1016/j.neuron.2013.03.016

59. Sheng M, Kim E. The shank family of scaffold proteins. J Cell Sci (2000) 113:1851-6.

60. Boeckers TM, Kreutz MR, Winter C, Zuschratter W, Smalla KH, Sanmarti-Vila $\mathrm{L}$, et al. Proline-rich synapse-associated protein-1/cortactin binding protein 1 (ProSAP1/CortBP1) is a PDZ-domain protein highly enriched in the postsynaptic density. J Neurosci (1999) 19:6506-18.

61. Baron MK, Boeckers TM, Vaida B, Faham S, Gingery M, Sawaya MR, et al. An architectural framework that may lie at the core of the postsynaptic density. Science (2006) 311:531-5. doi:10.1126/science.1118995

62. Grabrucker AM, Schmeisser MJ, Schoen M, Boeckers TM. Postsynaptic ProSAP/shank scaffolds in the cross-hair of synaptopathies. Trends Cell Biol (2011) 21:594-603. doi:10.1016/j.tcb.2011.07.003

63. Tsuriel S, Geva R, Zamorano P, Dresbach T, Boeckers T, Gundelfinger ED, et al. Local sharing as a predominant determinant of synaptic matrix molecular dynamics. PLoS Biol (2006) 4:e271. doi:10.1371/journal.pbio.0040271

64. Aoki C, Miko I, Oviedo H, Mikeladze-Dvali T, Alexandre L, Sweeney N, et al. Electron microscopic immunocytochemical detection of PSD-95, PSD-93, SAP-102, and SAP-97 at postsynaptic, presynaptic, and nonsynaptic sites of adult and neonatal rat visual cortex. Synapse (2001) 40:239-57. doi:10.1002/ syn. 1047

65. Lajoix AD, Gross R, Aknin C, Dietz S, Granier C, Laune D. Cellulose membrane supported peptide arrays for deciphering protein-protein interaction sites: the case of PIN, a protein with multiple natural partners. Mol Divers (2004) 8:281-90. doi:10.1023/B:MODI.0000036242.01129.27

66. Rapali P, Szenes A, Radnai L, Bakos A, Pál G, Nyitray L. DYNLL/LC8: a light chain subunit of the dynein motor complex and beyond. FEBS J (2011) 278:2980-96. doi:10.1111/j.1742-4658.2011.08254.x

67. Barbar E. Dynein light chain LC8 is a dimerization hub essential in diverse protein networks. Biochemistry (2008) 47:503-8. doi:10.1021/bi701995m

68. Yoshii A, Zhao JP, Pandian S, van Zundert B, Constantine-Paton MA. Myosin Va mutant mouse with disruptions in glutamate synaptic development and mature plasticity in visual cortex. J Neurosci (2013) 33:8472-82. doi:10.1523/ JNEUROSCI.4585-12.2013

69. Luo CX, Zhu DY. Research progress on neurobiology of neuronal nitric oxide synthase. Neurosci Bull (2011) 27:23-35. doi:10.1007/s12264-011-1038-0

70. Roszer T. The Biology of Subcellular Nitric Oxide. Heidelberg: Springer (2012).

71. Franceschini A, Szklarczyk D, Frankild S, Kuhn M, Simonovic M, Roth A, et al. STRING v9.1: protein-protein interaction networks, with increased coverage and integration. Nucleic Acids Res (2013) 41:D808-15. doi:10.1093/nar/ gks1094

72. Kuhn M, Szklarczyk D, Franceschini A, Mering C, Jensen LJ, Bork P. STITCH 3: zooming in on protein-chemical interactions. Nucleic Acids Res (2012) 40(D1):D876-80. doi:10.1093/nar/gkr1011

73. Navarro-Lérida I, Martínez Moreno M, Roncal F, Gavilanes F, Albar JP, Rodríguez-Crespo I. Proteomic identification of brain proteins that interact with dynein light chain LC8. Proteomics (2004) 4:339-46. doi:10.1002/pmic. 200300528

74. Kausar S, Asif M, Bibi N, Rashid S. Comparative molecular docking analysis of cytoplasmic dynein light chain DYNLL1 with pilin to explore the molecular mechanism of pathogenesis caused by Pseudomonas aeruginosa PAO. PLoS One (2013) 8:e76730. doi:10.1371/journal.pone.0076730

75. Mashiach E, Schneidman-Duhovny D, Andrusier N, Nussinov R, Wolfson HJ. FireDock: a web server for fast interaction refinement in molecular docking. Nucleic Acids Res (2008) 36:W229-32. doi:10.1093/nar/gkn186

76. Schneidman-Duhovny D, Inbar Y, Nussinov R, Wolfson HJ. PatchDock and SymmDock: servers for rigid and symmetric docking. Nucleic Acids Res (2005) 33:W363-7. doi:10.1093/nar/gki481

77. Guidolin D, Agnati LF, Tortorella C, Marcoli M, Maura G, Albertin G, et al. Neuroglobin as a regulator of mitochondrial-dependent apoptosis: a bioinformatics analysis. Int J Mol Med (2014) 33:111-6. doi:10.3892/ijmm.2013.1564

78. Sayle RA, Milner-White EJ. RASMOL: biomolecular graphics for all. Trends Biochem Sci (1995) 20:374. doi:10.1016/S0968-0004(00)89080-5

79. Raab M, Boeckers TM, Neuhuber WL. Proline-rich synapse-associated protein1 and 2 (ProSAP1/shank2 and ProSAP2/shank3)-scaffolding proteins are also present in postsynaptic specializations of the peripheral nervous system. Neuroscience (2010) 171:421-33. doi:10.1016/j.neuroscience.2010.08.041 
80. Huett A, Leong JM, Podolsky DK, Xavier RJ. The cytoskeletal scaffold shank3 is recruited to pathogen-induced actin rearrangements. Exp Cell Res (2009) 315:2001-11. doi:10.1016/j.yexcr.2009.04.003

81. Herbert MR. SHANK3, the synapse, and autism. N Engl J Med (2011) 365:173-5. doi:10.1056/NEJMcibr1104261

82. Daigo Y, Takayama I, Ward SM, Sanders KM, Fujino MA. Novel human and mouse genes encoding a shank-interacting protein and its upregulation in gastric fundus of W/WV mouse. J Gastroenterol Hepatol (2003) 18:712-8. doi:10.1046/j.1440-1746.2003.03046.x

83. Feyder M, Karlsson RM, Mathur P, Lyman M, Bock R, Momenan R, et al. Association of mouse Dlg4 (PSD-95) gene deletion and human DLG4 gene variation with phenotypes relevant to autism spectrum disorders and Williams' syndrome. Am J Psychiatry (2010) 167:1508-17. doi:10.1176/appi.ajp.2010. 10040484

84. Phelan K. 22q13.3 deletion syndrome. GeneReviews (2007).

85. Phelan M. Deletion 22q13.3 syndrome. Orphanet J Rare Dis (2008) 3:14. doi:10.1186/1750-1172-3-14

86. Phelan MC, Stapleton GA, Rogers RC. The Management of Genetic Syndromes. Hoboken: Wiley-Liss, Inc. (2010).

87. Grabrucker S, Jannetti L, Eckert M, Gaub S, Chhabra R, Pfaender S, et al. Zinc deficiency dysregulates the synaptic ProSAP/shank scaffold and might contribute to autism spectrum disorders. Brain (2014) 137:137-52. doi:10.1093/ brain/awt303

88. Guilmatre A, Huguet G, Delorme R, Bourgeron T. The emerging role of SHANK genes in neuropsychiatric disorders. Dev Neurobiol (2014) 74:113-22. doi:10.1002/dneu.22128

89. Soorya L, Kolevzon A, Zweifach J, Lim T, Dobry Y, Schwartz L, et al. Prospective investigation of autism and genotype-phenotype correlations in 22q13 deletion syndrome and SHANK3 deficiency. Mol Autism (2013) 4:18. doi:10.1186/ 2040-2392-4- 18

90. Phelan K, McDermid HE. The 22q13.3 deletion syndrome (Phelan-McDermid syndrome). Mol Syndromol (2012) 2:186-201. doi:10.1159/000334260

91. Kreienkamp HJ. Scaffolding proteins at the postsynaptic density: shank as the architectural framework. Handb Exp Pharmacol (2008) 186:365-80. doi:10.1007/978-3-540-72843-6_15

92. Lim S, Naisbitt S, Yoon J, Hwang JI, Suh PG, Sheng M, et al. Characterization of the shank family of synaptic proteins. Multiple genes, alternative splicing, and differential expression in brain and development. J Biol Chem (1999) 274:29510-8. doi:10.1074/jbc.274.41.29510

93. Naisbitt S, Kim E, Tu JC, Xiao B, Sala C, Valtschanoff J, et al. Shank, a novel family of postsynaptic density proteins that binds to the NMDA receptor/PSD-95/GKAP complex and cortactin. Neuron (1999) 23:569-82. doi:10.1016/S0896-6273(00)80809-0

94. Boeckers TM, Winter C, Smalla KH, Kreutz MR, Bockmann J, Seidenbecher $\mathrm{C}$, et al. Proline-rich synapse-associated proteins ProSAP1 and ProSAP2 interact with synaptic proteins of the SAPAP/GKAP family. Biochem Biophys Res Commun (1999) 264:247-52. doi:10.1006/bbrc.1999.1489

95. White JF. Intestinal pathophysiology in autism. Exp Biol Med (Maywood) (2003) 228:639-49.

96. Buie T, Fuchs GJ III, Furuta GT, Kooros K, Levy J, Lewis JD, et al. Recommendations for evaluation and treatment of common gastrointestinal problems in children with ASDs. Pediatrics (2010) 125:S19-29. doi:10.1542/peds.2009$1878 \mathrm{D}$

97. Verhoeven WM, Egger JI, Cohen-Snuijf R, Kant SG, de Leeuw N. PhelanMcDermid syndrome: clinical report of a 70-year-old woman. Am J Med Genet A (2013) 161A:158-61. doi:10.1002/ajmg.a.35597

98. Betalli P, Carretto E, Cananzi M, Zanatta L, Salvador R, Galeazzi F, et al. Autism and esophageal achalasia in childhood: a possible correlation? Report on three cases. Dis Esophagus (2013) 26:237-40. doi:10.1111/j.1442-2050.2012.01358.x

99. Chaidez V, Hansen RL, Hertz-Picciotto I. Gastrointestinal problems in children with autism, developmental delays or typical development. J Autism Dev Disord (2013). doi:10.1007/s10803-013-1973-x

100. Peeters B, Noens I, Philips EM, Kuppens S, Benninga MA. Autism spectrum disorders in children with functional defecation disorders. J Pediatr (2013) 163:873-8. doi:10.1016/j.jpeds.2013.02.028

101. Chandler S, Carcani-Rathwell I, Charman T, Pickles A, Loucas T, Meldrum D, et al. Parent-reported gastro-intestinal symptoms in children with autism spectrum disorders. J Autism Dev Disord (2013) 43:2737-47. doi:10.1007/s10803013-1768-0
102. Furuta GT, Williams K, Kooros K, Kaul A, Panzer R, Coury DL, et al. Management of constipation in children and adolescents with autism spectrum disorders. Pediatrics (2012) 130:S98-105. doi:10.1542/peds.2012-0900H

103. Wang L, Christophersen CT, Sorich MJ, Gerber JP, Angley MT, Conlon MA. Elevated fecal short chain fatty acid and ammonia concentrations in children with autism spectrum disorder. Dig Dis Sci (2012) 57:2096-102. doi:10.1007/s10620-012-2167-7

104. Wang LW, Tancredi DJ, Thomas DW. The prevalence of gastrointestinal problems in children across the United States with autism spectrum disorders from families with multiple affected members. J Dev Behav Pediatr (2011) 32:351-60. doi:10.1097/DBP.0b013e31821bd06a

105. Pang KH, Croaker GD. Constipation in children with autism and autistic spectrum disorder. Pediatr Surg Int (2011) 27:353-8. doi:10.1007/s00383-0102680-8

106. Erickson CA, Stigler KA, Corkins MR, Posey DJ, Fitzgerald JF, McDougle CJ. Gastrointestinal factors in autistic disorder: a critical review. J Autism Dev Disord (2005) 35:713-27. doi:10.1007/s10803-005-0019-4

107. Simonoff E, Pickles A, Charman T, Chandler S, Loucas T, Baird G. Psychiatric disorders in children with autism spectrum disorders: prevalence, comorbidity, and associated factors in a population-derived sample. J Am Acad Child Adolesc Psychiatry (2008) 47:921-9. doi:10.1097/CHI.0b013e318179964f

108. Dalrymple NJ, Ruble LA. Toilet training and behaviors of people with autism: parent views. J Autism Dev Disord (1992) 22:265-75. doi:10.1007/BF01058155

109. Matson JL. Simple correction for treating an autistic boy's encopresis. Psychol Rep (1977) 41:802. doi:10.2466/pr0.1977.41.3.802

110. Rodríguez-Crespo I, Yélamos B, Roncal F, Albar JP, Ortiz de Montellano PR, Gavilanes F. Identification of novel cellular proteins that bind to the LC8 dynein light chain using a pepscan technique. FEBS Lett (2001) 503:135-41. doi:10.1016/S0014-5793(01)02718-1

111. Arons MH, Thynne CJ, Grabrucker AM, Li D, Schoen M, Cheyne JE, et al. Autism-associated mutations in ProSAP2/shank3 impair synaptic transmission and neurexin-neuroligin-mediated transsynaptic signaling. J Neurosci (2012) 32:14966-78. doi:10.1523/JNEUROSCI.2215- 12.2012

112. Südhof TC. Neuroligins and neurexins link synaptic function to cognitive disease. Nature (2008) 455:903-11. doi:10.1038/nature07456

113. Gershon MD, Ratcliffe EM. Developmental biology of the enteric nervous system: pathogenesis of Hirschsprung's disease and other congenital dysmotilities. Semin Pediatr Surg (2004) 13:224-35. doi:10.1053/j.sempedsurg.2004.10.019

114. Chaudhury A. Evidence for dual pathway for nitrergic neuromuscular transmission in doubt: evidence favors lack of role of ICC. Gastroenterology (2013) 145:1160-1. doi:10.1053/j.gastro.2013.09.039

115. Lancaster JR Jr. A tutorial on the diffusibility and reactivity of free nitric oxide. Nitric Oxide (1997) 1:18-30. doi:10.1006/niox.1996.0112

116. Park E, Moonseok N, Jeonghoon C, Seho K, Jae-Ran L, Jiyoung Y, et al. The shank family of postsynaptic density proteins interacts with and promotes synaptic accumulation of the beta PIX guanine nucleotide exchange factor for Racl and Cdc42. J Biol Chem (2003) 278:19220-9. doi:10.1074/jbc. M301052200

117. Goyal RK, Chaudhury A. Pathogenesis of achalasia: lessons from mutant mice. Gastroenterology (2010) 139:1086-90. doi:10.1053/j.gastro.2010.08.013

118. Zizer E, Beilke S, Bäuerle T, Schilling K, Möhnle U, Adler G, et al. Loss of Lsc/p115 protein leads to neuronal hypoplasia in the esophagus and an achalasia-like phenotype in mice. Gastroenterology (2010) 139:1344-54. doi:10.1053/j.gastro.2010.06.041

119. Sato D, Lionel AC, Leblond CS, Prasad A, Pinto D, Walker S, et al. SHANK1 deletions in males with autism spectrum disorder. Am J Hum Genet (2012) 90:879-87. doi:10.1016/j.ajhg.2012.03.017

120. Leblond CS, Heinrich J, Delorme R, Proepper C, Betancur C, Huguet G, et al. Genetic and functional analyses of SHANK2 mutations suggest a multiple hit model of autism spectrum disorders. PLoS Genet (2012) 8:e1002521. doi:10.1371/journal.pgen.1002521

121. Schmeisser MJ, Ey E, Wegener S, Bockmann J, Stempel AV, Kuebler A, et al. Autistic-like behaviours and hyperactivity in mice lacking ProSAP1/shank2. Nature (2012) 486:256-60. doi:10.1038/nature11015

122. Chaudhury A, He XD, Goyal RK. Role of myosin Va in purinergic vesicular neurotransmission in the gut. Am J Physiol Gastrointest Liver Physiol (2012) 302:G598-607. doi:10.1152/ajpgi.00330.2011

123. Yang M, Bozdagi O, Scattoni ML, Wöhr M, Roullet FI, Katz AM, et al. Reduced excitatory neurotransmission and mild autism-relevant phenotypes 
in adolescent shank3 null mutant mice. J Neurosci (2012) 32:6525-41. doi:10. 1523/JNEUROSCI.6107-11.2012

124. Wang X, McCoy PA, Rodriguiz RM, Pan Y, Je HS, Roberts AC, et al. Synaptic dysfunction and abnormal behaviors in mice lacking major isoforms of shank3. Hum Mol Genet (2011) 20:3093-108. doi:10.1093/hmg/ddr212

125. Peça J, Feliciano C, Ting JT, Wang W, Wells MF, Venkatraman TN, et al. Shank3 mutant mice display autistic-like behaviours and striatal dysfunction. Nature (2011) 472:437-42. doi:10.1038/nature09965

126. Yoo J, Bakes J, Bradley C, Collingridge GL, Kaang BK. Shank mutant mice as an animal model of autism. Philos Trans R Soc Lond B Biol Sci (2013) 369:20130143. doi:10.1098/rstb.2013.0143

127. Pardo CA, Eberhart CG. The neurobiology of autism. Brain Pathol (2007) 17:434-47. doi:10.1111/j.1750-3639.2007.00102.x

128. Bourgeron T. A synaptic trek to autism. Curr Opin Neurobiol (2009) 19:231-4. doi:10.1016/j.conb.2009.06.003

129. Won H, Mah W, Kim E. Autism spectrum disorder causes, mechanisms, and treatments: focus on neuronal synapses. Front Mol Neurosci (2013) 6:19. doi:10.3389/fnmol.2013.00019

130. Wang X, Bey AL, Chung L, Krystal AD, Jiang YH. Therapeutic approaches for shankopathies. Dev Neurobiol (2014) 74:123-35. doi:10.1002/ dneu. 22084

131. Carbonetto S. A blueprint for research on shankopathies: a view from research on autism spectrum disorder. Dev Neurobiol (2014) 74:85-112. doi:10.1002/ dneu. 22150
132. Canitano R. Novel treatments in autism spectrum disorders: from synaptic dysfunction to experimental therapeutics. Behav Brain Res (2013) 251:125-32. doi:10.1016/j.bbr.2012.11.024

133. Schuetz G, Rosário M, Grimm J, Boeckers TM, Gundelfinger ED, Birchmeier W. The neuronal scaffold protein shank3 mediates signaling and biological function of the receptor tyrosine kinase Ret in epithelial cells. J Cell Biol (2004) 167:945-52. doi:10.1083/jcb.200404108

Conflict of Interest Statement: The author declares that the research was conducted in the absence of any commercial or financial relationships that could be construed as a potential conflict of interest.

Received: 18 February 2014; accepted: 27 March 2014; published online: 10 April 2014. Citation: Chaudhury A (2014) Molecular handoffs in nitrergic neurotransmission. Front. Med. 1:8. doi: 10.3389/fmed.2014.00008

This article was submitted to Gastroenterology, a section of the journal Frontiers in Medicine.

Copyright () 2014 Chaudhury. This is an open-access article distributed under the terms of the Creative Commons Attribution License (CC BY). The use, distribution or reproduction in other forums is permitted, provided the original author(s) or licensor are credited and that the original publication in this journal is cited, in accordance with accepted academic practice. No use, distribution or reproduction is permitted which does not comply with these terms. 